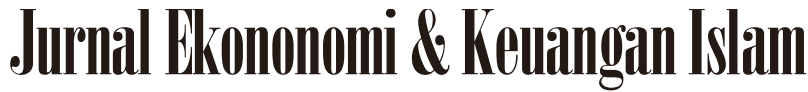

\author{
Available at http://journal.uii.ac.id/index.php/jeki
}

\section{Analisis perbandingan kinerja saham syariah antara DJIMI, FSTE GIIS, KLSESI, dan JII}

\author{
Novita Kusuma Maharani \\ Universitas Gadjah Mada, Yogyakarta \\ e-mail: vhyta.maharani@gmail.com
}

\begin{tabular}{l} 
Keywords: \\
Sharia stock screening, Sharia \\
index performance, Sharia \\
stock performance, Sharia \\
capital market \\
DOI: \\
10.20885/JEKI.vol3.iss1.art2 \\
\hline
\end{tabular}

DOI:
10.20885/JEKI.vol3.iss1.art2

\begin{abstract}
This research investigates whether the difference of Sharia stock screening mechanism in some countries will influence the index and stock performance. Some countries have a tight screening policy and the other countries have a loose screening policy. This research investigates 4 Sharia indices DJIMI, FTSE GIIS, KLSESI, and JII since October 2012 until September 2014. This research shows that the performance of the Sharia stock index is not affected by how tight the screening process of that index. Although KLSESI index has the tightest stock screening policy, but the performance is not different with the Sharia stock which has loosest stock screening policy which is DJMI index. When we compare the return of each index, the performance of the 4 indices shows insignificant different. The performance of JII stock which has the looser stock screening policy is also not different with the KLSESI stock performance which has the tighter stock screening policy.
\end{abstract}

\begin{abstract}
Abstrak
Penelitian ini menginvestigasi mekanisme penyaringan saham syariah di beberapa negara yang mempengaruhi kinerja indeks dan saham. Beberapa negara memiliki kebijakan penyaringan yang ketat dan negara-negara lain memiliki kebijakan penyaringan yang longgar. Penelitian ini meneliti 4 indeks Syariah DJIMI, FTSE GIIS, KLSESI, dan JII sejak Oktober 2012 sampai September 2014. Penelitian ini menunjukkan bahwa kinerja indeks saham Syariah tidak terpengaruh oleh seberapa ketatnya proses penyaringan dari indeks tersebut. Meski indeks KLSESI memiliki kebijakan penyaringan saham yang ketat, namun kinerjanya tidak berbeda dengan saham Syariah yang memiliki kebijakan penyaringan saham longgar yaitu indeks DJMI. Ketika kita membandingkan kembalinya masing-masing indeks, kinerja dari 4 indeks menunjukkan perbedaan yang tidak signifikan juga. Kinerja saham JII yang memiliki kebijakan penyaringan saham yang longgar juga tidak berbeda dengan kinerja saham KLSESI yang memiliki kebijakan penyaringan saham yang ketat.
\end{abstract}

\section{Pendahuluan}

Undang-Undang No. 8 Tahun 1995 tentang pasar modal menyatakan bahwa yang dimaksud pasar modal ialah kegiatan yang berhubungan dengan penawaran umum dan perdagangan efek, perusahaan publik yang berkaitan dengan efek yang diterbitkannya, serta lembaga dan profesi yang berkaitan dengan efek. Dengan demikian dapat disimpulkan bahwa pasar modal dapat diartikan merupakan tempat dimana para penjual dan pembeli melakukan transaksi dengan tujuan memperoleh modal. (Nurlatifah, 2015).

Kegiatan pasar modal yang dilaksanakan berdasarkan prinsip-prinsip syariah disebut pasar modal syariah. Prinsip syariah berarti kegiatan yang dilakukan harus sesuai dan tidak bertentangan dengan prinsip dan hukum Islam. (Hadita \& Taufikurohman, 2011) Dengan demikian, efek yang diperdagangkan merupakan efek yang sesuai dengan prinsip-prinsip syariah di pasar modal. Hal ini telah diatur dalam Peraturan Bapepam-LK Nomor II.K.1 tentang Kriteria dan Penerbitan Daftar Efek Syariah dikatakan bahwa Daftar Efek Syariah adalah "Kumpulan efek yang tidak bertentangan dengan prinsip-prinsip syariah di pasar modal".

Dalam perkembangannya, pasar modal syariah sekarang ini mengalami pertumbuhan yang sangat pesat. Tidak hanya negara-negara yang bermayoritas muslim yang melakukan investasi di pasar modal syariah, tetapi juga negara-negara minoritas seperti Amerika, Inggris, Jerman, dan negara barat lainnya mulai membuka peluang investasi yang berbasis syariah. Indeks saham syariah pertama kali muncul di negara minoritas muslim yaitu Amerika Serikat, setelah The Amana Fund didirikan oleh The North American Islamic Trust pada tahun 1986 (Achsien, 2000). Sampai saat ini, sudah banyak terdapat bursa yang mulai memunculkan indeks syariah seperti, Dow Jones Islamic Market Indices (DJIMI), Kuala Lumpur Stock Exchange Shariah Index (KLSESI),FTSE Global Islamic Indices, the Wellington Islamic Index, dan the Citi Bank Islamic Index. 
Perusahaan-perusahaan yang telah termasuk dalam indeks saham syariah merupakan perusahaan yang telah memenuhi kriteria Islam. Kriteria tersebut mewajibkan bagi setiap indeks untuk tidak memasukkan sahamsaham dari perusahaan yang kegiatan intinya berkaitan dengan : perbankan atau aktivitas lain yang berhubungan dengan bunga, alkohol, rokok, perjudian, perusahaan senjata, perusahaan makanan haram (babi), dan lain sebagainya. Selain itu perusahaan juga harus memperhatikan total hutang berbasis bunga dan total pendapatan bunga yang diperoleh dalam aktivitasnya.

Dalam konteks indeks saham syariah, Dow Jones Islamic Market Indices (DJIMI) dikenalkan pertama kali pada tahun 1999 dan menjadi benchmark pertama yang mewakili indeks-indeks islami lainnya. Penyaringan di DJIMI mengadopsi kriteria yang dibentuk oleh AAOIFI (Auditing and Accounting Organization of Islamic Financial Institutions)-standard 21. Dengan demikian, indeks DJIMI telah memenuhi standar penyaringan Islam (islamic screening). Dow Jones World Index disaring berdasarkan kriteria kuantitatif yang dibuat oleh Dow Jones Index untuk memperkirakan pembatasan yang biasanya digunakan oleh shariah-compliant dan relevan terhadap indeks tertentu.

FTSE Global Islamic Indicies (GIIS) yang didirikan pada Oktober 1999 ini dirancang untuk mengidentifikasi dan mencari para investor yang kompatibel dalam perdagangan ekuitas islam secara global dengan cara yang analog dengan indeks yang mengidentifikasi dan mencari para investor yang relevan pada ekuitas perdagangan publik, yang tidak memiliki adanya batasan-batasan yang dikenakan dalam ajaran syariah islam dalm proses seleksi. Yang demikian merupakan indikator dari pasar saham syariah.

Kuala Lumpur Syariah Index (KLSESI) didirikan pada tahun 1999 sebagai sarana bagi investor untuk berinvestasi dengan benchmark (patokan) pada shariah-compliant yang mana perusahaan-perusahaan tersebut telah terdaftar di Bursa Malaysia. Saham-saham syariah yang terdaftar di Bursa Malaysia telah disetujui dan diizinkan oleh Dewan Penasehat Syariah (SAC) dari Komisi Sekuritas (SC) yang ada di Malaysia. Tidak ada pemisahan proses screening syariah dalam pemilihan efek untuk indeks syariah.

Jakarta Islamic Index (JII) merupakan salah satu indeks saham syariah yang ada di Bursa Efek Indonesia dengan ketentuan saham tersebut telah sesuai dan tidak bertentangan dengan prinsip syariah. Berawal dari kerjasama yang dilakukan antara PT Danareksa Investment dan PT Bursa Efek Jakarta (sekarang BEI) pada 3 Juli 2000 yang bertujuan untuk meningkatkan kepercayaan para investor dalam berinvestasi di pasar modal yang berbasis pada prinsip syariah serta tidak bertentangan terhadap apa yang dilarang dalam Islam. (Basri, 2014).

Dari sekian banyaknya saham syariah yang terdapat di Daftar Efek Syariah (DES), terdapat 30 saham syariah yang terdaftar di JII dengan syarat tambahan yaitu berdasarkan tingkat likuiditas dan nilai kapitalisasi yang cukup besar di Bursa dengan pengkajian ulang (penyaringan) setiap 6 bulan sekali. Dengan dilakukannya pengkajian ulang dapat diketahui saham-saham mana saja yang masih sesuai dengan ketentuan, dimungkinkan juga terdapat saham baru yang sebelumnya tidak terdaftar di JII atau sangat dimungkinkan pula saham yang sebelumnya terdaftar di JII pada periode selanjutnya tidak lagi terdaftar di JII.

Dalam hal mekansime screening saham syariah, Obaidullah (2008) menegaskan bahwa kriteria kriteria untuk screening saham dapat berdampak positif dan negatif. Untuk kriteria positif mungkin akan memberikan sesuatu yang penting dalam membangun sebuah perusahaan dengan portofolio yang tersebar secara luas untuk alasan seperti kualitas produk, menjaga hubungan baik dengan para konsumen, adanya kontrol dalam penanganan polusi, manajemen hutan yang berkelanjutan, dan melakukan konservasi pada energi. Trevor (2006) telah mencatat sektor-sektor, bisnis, dan perusahaan yang mungkin akan dikeluarkan dalam daftar investasi syariah: 1) Perusahaan yang memproduksi minuman yang beralkohol. 2) Perusahaan yang memperoduksi daging babi dan produk yang berhungan dengan babi. 3) Perusahaan yang terlibat dalam gambling, lottre, dan permainan judi lainnya. 4) Perusahaan yang aktivitasnya berbasis pada produksi hiburan. 5) Perusahaan yang memproduksi senjata. 6) Perusahaan yang memproduksi rokok, tobacco dan semacamnya. 7) Perusahaan yang berhubungan dengan jual-beli janin. 8) Perusahaan yang berhubungan dengan kloning manusia. 9) Bank dan institusi keuangan konvensional. 10) Perusahaan dengan impure melebihi 5\% dari penerimaan. Tabel 1 menampilkan detail dari kriteria screening menggunakan Shariah Board of Major Islamic Index.

Dalam konteks riset, kebanyakan dari penelitian yang membandingkan kinerja pada indeks yang berbeda-beda masih belum dapat memberikan hasil yang signifikan. Penelitian yang dilakukan oleh Hussein (2004) yang menguji perbandingan kinerja antara FTSE Global Islamic Indices dengan FTSE All-World Index selama periode 1996-2003. Hasil dari penelitian tersebut menunjukkan bahwa tidak ada perbedaan yang signifikan antara kedua indeks yang berarti kinerja FTSE Global Islamic Indices sama baiknya dengan kinerja FTSE All-World Index. Bukti dari hasil penelitian tersebut mengatakan bahwa indeks syariah menghasilkan abnormal return yang positif selama periode bull (naik), meskipun kinerja tersebut masih berada pada urutan di bawah Ideks FTSE All-World pada periode bear (naik). Hasil dari penelitian secara umum juga menunjukkan bahwa penerapan screening berdasarkan etika tidak memiliki dampak yang berlawanan pada kinerja indeks FTSE Global Islamic. 
Tabel 1. Kriteria Screening Indeks Saham Syariah Yang Utama

\begin{tabular}{|c|c|c|}
\hline Index families & Debt screens & Receivable screens \\
\hline $\begin{array}{l}\text { Dow Jones Islamic } \\
\text { Market Index }\end{array}$ & $\begin{array}{c}\text { Total debts / Trailing } 24 \text { month average } \\
\text { market capitalization } \\
>33 \%\end{array}$ & $\begin{array}{c}\text { Total receivables / Trailing } 24 \text { month average } \\
\text { market capitalization } \\
>33 \%\end{array}$ \\
\hline FTSE Global Islamic & Total debts $<33 \%$ & Total receivables $<50 \%$ \\
\hline Indices & Total assets & Total assets \\
\hline Kuala lumpur Shariah & Total debts $<33 \%$ & Total receivables $<33 \%$ \\
\hline Index (SAC of Malaysia) & Total assets & Total assets \\
\hline Jakarta Islamic Index & $\frac{\text { Total debts }}{\text { Total assets }}<45 \%$ & $\frac{\text { Total receivables }}{\text { Total assets }}<10 \%$ \\
\hline
\end{tabular}

Penelitian selanjutnya dilakukan oleh Hanafi (2012) yang membandingkan kinerja saham syariah dan saham konvensional. Untuk saham syariah peneliti menggunakan indeks JII Jakarta Islamic Index) dan untuk saham konvensional menggunakan indeks LQ45. Peneliti mengukur kinerja tersebut dengan return dan risiko dari JII dan LQ45, yaitu dengan metode Sharpe Ratio, Treynor Ratio, dan Jensen alpha. Hasil dari penelitian tersebut juga menunjukkan perbedaan yang tidak signifikn antara indeks JII dan LQ45. Meskipun hasil penelitian tersebut memberikan return yang lebih tinggi pada indeks saham LQ45. Hasil dari penelitian ini juga membuktikan bahwa investasi etis layak dilakukan karena dapat memenuhi tujuan etis tanpa harus mengorbankan tujuan ekonomis.

Penelitian ini akan membahas tentang analisis perbandingan kinerja indeks saham syariah pada Dow Jones Islamic Market Index (DJIMII), FTSE Global Islamic Indices (FTSE GIIS), Kuala Lumpur Stock Exchange Islamic Index (KLSESI), dan Jakarta Islamic Index (JII). Apakah perbedaan kriteria di masing-masing indeks tersebut mempengaruhi kinerja masing-masing. Dengan adanya penelitian ini diharapkan dapat menjadi sebuah perbandingan bagaimana penerapan mekanisme screening serta kinerja di masing-masing negara, apakah dengan adanya perbedaan tersebut dapat menjadi suatu keragaman dari indeks-indeks syariah yang berbeda dan juga sebagai upaya bagi pemerintah dalam amenanggapi perbedaan tersebut agar bisa mengharmonisasikan dari adanya perbedaan tersebut.

\section{Metode Penelitian}

Populasi pada penelitian ini adalah pasar modal syariah yang berada di beberapa negara yang memiliki indeks saham syariah. Sampel pada penelitian ini adalah indeks saham syariah di masing-masing negara terpilih yaitu Jakarta Islamic Index (JII), FTSE Bursa EMAS Shariah (FBMS Shariah), Financial Times Stock Exchange SGX Asia Shariah 100 (FTSE SGX Asia Shariah 100), dan Dow Jones Islamic Market Index (DJIMI).Teknik sampel yang digunakan adalah Purposive Sampling, dimana sampel telah ditentukan terlebih dahulu oleh peneliti. Untuk perbandingan indeks (JII, FBMS Shariah, FTSE SGX Asia Shariah 100, DJIMI) menggunakan data harga saham bulanan periode Oktober 2012 sampai September 2014. Sedangkan untuk perbandingan saham (JII dan FBMS Shariah) menggunakan data harga saham bulanan periode Januari 2011 sampai Desember 2013.

Variabel pada penelitian ini meliputi : 1) Kinerja indeks saham syariah yang dilihat dari return aktual indeks saham. 2) Kinerja saham syariah diukur dengan abnormal return. Langkah menghitung abnormal return diawali dengan menghitung return saham kemudian return tersebut dikurangi dengan return ekspektasi dengan metode MAM (market adjusted model) yaitu model yang menganggap bahwa penduga yang terbaik untuk mengestimasi return suatusekuritas adalah return indeks pasar saat ini (Hartono, 2013). Sedangkan analisis pada penelitian ini menggunakan uji beda rata-rata. Uji beda rata-rata untuk mengetahui pengaruh mekanisme screening saham terhadap kinerja indeks saham syariah yang ada di masing-masing negara. Uji beda rata-rata dapat dilakukan dengan menggunakan uji T. Uji T merupakan uji statistik dengan membandingkan rata-rata dua kelompok data.

\section{Hasil dan Pembahasan}

\section{Perbandingan Kinerja Indeks Saham Syariah}

Pada tabel 2 ditunjukkan bahwa kinerja indeks saham syariah antara JII dan FBMS secara statistik memiliki perbedaan yang tidak signifikan. Hal ini ditunjukkan dengan probabilitas di masing-masing indeks yaitu sebesar 0.9632 , perbedaan secara signifikan terjadi jika besar probabilitas yang dihasilkan kurang dari 0,1 . Namun secara absolut, terlihat bahwa kinerja JII masih berada di bawah kinerja FBMS Shariah yaitu sebesar 0.006218 pada JII, dan 0,006632 pada FBMS Shariah.

Pada tabel 3 juga ditunjukkan bahwa kinerja indeks saham syariah antara JII dan FTSE SGX Asia Shariah 100 secara statistik tidak juga memiliki perbedaan yang signifikan. Probabilitas yang dihasilkan sebesar 
0.8716. Namun dilihat dari mean masing-masing indeks, terlihat bahwa kinerja JII juga masih berada di bawah kinerja FTSE SGX Asia Shariah 100 yaitu sebesar 0.006218 pada JII, dan 0,007621 pada FTSE SGX Asia Shariah 100.

Tabel 2. Hasil Perbandingan Kinerja Indeks JII dan Indeks FBMS Shariah

\begin{tabular}{|c|c|c|c|c|}
\hline \multicolumn{2}{|l|}{ Method } & Df & Value & Probability \\
\hline \multicolumn{2}{|l|}{ t-test } & 46 & 0.0463 & 0.9632 \\
\hline \multicolumn{2}{|c|}{ Anova F-statistic } & $(1,46)$ & 0.0021 & 0.9632 \\
\hline Variable & Count & Mean & Std. Dev. & $\begin{array}{l}\text { Std. Err. } \\
\text { of Mean }\end{array}$ \\
\hline JII & 24 & 0.0062 & 0.0347 & 0.0071 \\
\hline FBMS & 24 & 0.0066 & 0.0265 & 0.0054 \\
\hline All & 48 & 0.0064 & 0.0306 & 0.0044 \\
\hline
\end{tabular}

Tabel 3. Hasil Perbandingan Kinerja Indeks JII dan Indeks FTSE SGX Asia Shariah

\begin{tabular}{|c|c|c|c|c|}
\hline \multicolumn{2}{|l|}{ Method } & Df & Value & Probability \\
\hline \multicolumn{2}{|l|}{ t-test } & 46 & 0.1625 & 0.8716 \\
\hline \multicolumn{2}{|c|}{ Anova F-statistic } & $(1,46)$ & 0.0264 & 0.8716 \\
\hline Variable & Count & Mean & Std. Dev. & $\begin{array}{l}\text { Std. Err. } \\
\text { of Mean }\end{array}$ \\
\hline JII & 24 & 0.0062 & 0.0347 & 0.0071 \\
\hline FTSE & 24 & 0.0076 & 0.0240 & 0.0049 \\
\hline All & 48 & 0.0069 & 0.0296 & 0.0042 \\
\hline
\end{tabular}

Tabel 4 juga menunjukkan bahwa kinerja indeks saham syariah antara JII dan DJIMII secara statistik juga tidak berbeda secara signifikan. Hal ini terlihat dari besar probabilitas masing-masing indeks sebesar 0,7296. Namun secara absolut, terlihat bahwa kinerja JII juga masih berada di bawah kinerja DJIMII yaitu sebesar 0.006218 pada JII, dan 0,009282 pada DJIM.

Tabel 4. Hasil Perbandingan Kinerja Indeks JII dan Indeks DJIMII

\begin{tabular}{lllll}
\hline \hline Method & Df & Value & Probability \\
\hline \hline t-test & 46 & 0.3478 & 0.7296 \\
Anova F-statistic & $(1,46)$ & 0.1209 & 0.7296 \\
\hline \hline & & & & Std. Err. \\
Variable & Count & Mean & Std. Dev. & of Mean \\
\hline JII & 24 & 0.0062 & 0.0347 & 0.0071 \\
DJMII & 24 & 0.0093 & 0.0255 & 0.0052 \\
\hline All & 48 & 0.0077 & 0.0302 & 0.0043 \\
\hline \hline
\end{tabular}

\section{Perbandingan Kinerja Saham Syariah antara JII dan FBMS Syariah}

Untuk melihat perbandingan secara rinci, peneliti mencoba mengelompokkan return tersebut dengan menganalisis per-periode : (i) Januari - Desember 2011, (ii) Januari - Desember 2012, (iii) Januari - Desember 2013, dan keseluruhan periode (iv) Januari 2011 - Desember 2013. Hasil perbandingan kedua saham disajikan pada Tabel 5. 
Tabel 5. Hasil Perbandingan Return Kinerja Saham JII dan Saham FBMS Shariah Periode Januari 2011 - Desember 2013

\begin{tabular}{lcccccccc}
\hline & \multicolumn{2}{c}{2011} & \multicolumn{2}{c}{2012} & \multicolumn{2}{c}{2013} & \multicolumn{2}{c}{$2011-2013$} \\
\cline { 2 - 8 } & $\mathrm{P}$ & Mean & $\mathrm{P}$ & Mean & $\mathrm{P}$ & Mean & $\mathrm{P}$ & Mean \\
\hline JII & 0.9 & 0.002 & 0.7 & 0.008 & 0.1 & 0.004 & 0.4 & 0.004 \\
FBMS & & 0.002 & & 0.005 & & 0.156 & & 0.008 \\
\hline
\end{tabular}

Hasil analisis tersebut (Tabel 5) terlihat bahwa saham JII dan FBMS tidak berbeda signifikan dengan probabilitas yang dihasilkan sangat besar. Pada periode 2011 dan 2013 kinerja saham FBMS Shariah menunjukkan performa yang lebih baik dibandingkan dengan saham JII dengan nilai rata-rata (mean) : (1) Januari - Desember 2011 sebesar 0,0024 (FBMS Shariah) dan 0.0023 (JII), (2) Januari - Desember 2013 sebesar 0.1561 (FBMS Shariah) dan 0.0083 (JII). Sedangkan pada periode 2012 saham JII menunjukkan performa yang lebih baik dibandingkan dengan saham FBMS Shariah yang dilihat dari nilai rata-rata (mean) yang dihasilkan sebesar 0.008281 (JII) dan 0.0052 (FBMS Shariah). Kemudian hasil perbandingan dari keseluruhan periode (2011-2013) dapat disimpulkan bahwa saham FBMS Shariah mempunyai performa yang lebih baik dibandingkan dengan saham JII dengan nilai rata-rata (mean) sebesar 0.0035 (JII) dan 0.0077 (FBMS Shariah).

\section{Perbandingan Abnormal Return Saham Syariah}

Hasil dari analisis perbandingan saham JII dan FBMS dengan membandingkan abnormal return dari kedua saham masing-masing periode Januari hingga Desember 2011 dapat dilihat pada tabel 6. Besar probabilitas dari kedua indeks saham tidak memiliki perbedaan yang signifikan.

Tabel 6. Hasil Perbandingan Abnormal Return Kinerja Saham JII dan Saham FBMS Shariah Periode Januari 2011 - Desember 2013

\begin{tabular}{lcccccccc}
\hline & \multicolumn{2}{c}{2011} & \multicolumn{2}{c}{2012} & \multicolumn{2}{c}{2013} & \multicolumn{2}{c}{$2011-2013$} \\
\cline { 2 - 8 } & $\mathrm{P}$ & Mean & $\mathrm{P}$ & Mean & $\mathrm{P}$ & Mean & $\mathrm{P}$ & Mean \\
\hline JII & 0.8 & -0.0020 & 0.6 & -0.000 & 0.7 & 0.0010 & 0.9 & -0.0003 \\
FBMS & & -0.0004 & & -0.0044 & & 0.0100 & & $-3.98 \mathrm{E}$ \\
\hline
\end{tabular}

Pada periode 2011 dan 2013 kinerja saham FBMS Shariah menunjukkan performa yang lebih baik dibandingkan dengan saham JII dengan nilai rata-rata (mean) : (1) Januari - Desember 2011 sebesar -0,0003 (FBMS Shariah) dan -0.0021 (JII), (2) Januari - Desember 2013 sebesar 0.0047 (FBMS Shariah) dan 0.001121 (JII). Sedangkan pada periode 2012 saham JII menunjukkan performa yang lebih baik dibandingkan saham FBMS Shariah yang dilihat dari nilai rata-rata (mean) yang dihasilkan sebesar -0.0000 (JII) dan -0.0044 (FBMS Shariah). Kemudian hasil perbandingan dari keseluruhan periode (2011-2013) dapat disimpulkan bahwa saham FBMS Shariah mempunyai performa yang lebih baik dibandingakn dengan saham JII dengan nilai rata-rata (mean) sebesar -0.0003 (JII) dan -0.0000 (FBMS Shariah).

Melihat hasil dari penelitian tersebut, penerapan kebijakan screening saham di berbagai negara memiliki cara yang bervariasi. Semua kebijakan tersebut ditentukan oleh peraturan maupun undang-undang yang berlaku di negara tersebut. Semua kebijakan yang dilakukan tentu saja bertujuan untuk mendorong pertumbuhan pasar modal syariah di masing-masing negara yang dapat kita lihat dari kinerja saham syariah tersebut. Karena perbedaan penerapan kebijakan itulah maka kinerja yang dihasilkan juga memiliki perbedaan. Berdasarkan kriteria screening indeks saham syariah syariah di berbagai Negara tersebut diperoleh hasil bahwa kriteria screening yang memiliki kebijakan paling ketat yaitu kriteria screening pada indeks KLSESI (Kuala Lumpur Stock Exchange Shariah Index) yang didasarkan pada kebijakan Shariah Advisory Council of Malaysia (SAC) dengan total hutang dibagi dengan total aset tidak melebihi $33 \%(<33 \%)$ dan total piutang dibagi dengan total aset tidak melebihi 33\% (<33\%). Menurut Komisi Sekuritas (SC) Malaysia, fokus pada pengujian screening tersebut didasarkan pada aktivitas utama (primary activity) dengan melihat pada barang dan jasa yang ditawarkan. (Securities Comission resolutions : 145 - 149).

Kemudian diikuti dengan kebijakan kriteria screening pada indeks FTSE Global Islamic dengan total hutang dibagi dengan total aset tidak melebihi 33\% $(<33 \%)$ dan total piutang dibagi dengan total aset tidak melebihi 50\% (<50\%). Pada proses penentuan screening FTSE GIIS berada di bawah naungan konsultan syariah yaitu Yaasar Limited sebagai pedoman dari peraturan kebijakan screening saham (ftse-globalshariah.com).

Selanjutnya kebijakan screening pada Jakarta Islamic Index (JII) dengan total hutang yang dibagi dengan total asset tidak melebihi $45 \%(<45 \%)$ dan total piutang tidak melebihi $10 \%(<10 \%)$. Hal ini sesuai dengan peraturan Bapepam-LK Nomor II.K.1 tentang Kriteria dan Penerbitan Daftar Efek Syariah, pasal 1.b.7. 
dengan ketentuan bahwa perusahaan tersebut tidak melakukan usaha atau aktivitas yang bertentangan dengan prinsip syariah (bapepam.co.id).

Kebijakan kriteria screening saham yang paling longgar yaitu pada indeks DJIMI dengan total hutang dibagi rata-rata kapitalisasi pasar dengan perputaran (trailing) sebanyak 24 bulan tidak melebihi $33 \%(<33 \%)$ dan total piutang yang juga dibagi dengan rata-rata kapitalisasi pasar (trailing 24-month) juga tidak melebihi $33 \%(<33 \%)$. Screening tersebut berdasarkan kriteria yang telah ditentukan oleh DJIMI Index Shariah Supervisory Board untuk mengeleminasi perusahaan-perusahaan yang tidak memenuhi syarat syariah dan perusahaan dengan tingkat hutang tinggi atau pendapatan yang tidak murni karena adanya bunga (djindexes.com).

Tabel 7. Selisih Nilai Rata-Rata (Mean) Indeks Saham Syariah

\begin{tabular}{lcl}
\multicolumn{1}{c}{ Indeks Saham Syariah } & Selisih Mean & \multicolumn{1}{c}{ Keterangan } \\
\hline JII - FBMS Shariah & $-0.04 \%$ & JII $<$ FBMS \\
JII - FTSE SGX Asia Shariah & $-0.14 \%$ & JII $<$ FTSE SGX \\
JII - DJIMI & $-0.31 \%$ & JII $<$ DJIMII \\
\hline
\end{tabular}

Hasil mean pada tabel di atas (Tabel 7) membuktikan bahwa perbedaan kinerja indeks saham syariah yang tidak signifikan. Selisih mean yang pertama, antara indeks JII dan FBMS Shariah terlihat bahwa kinerja kedua indeks hanya berbeda sebesar $-0.04 \%$ dengan indeks FBMS Shariah memiliki kinerja lebih baik dibandingkan dengan indeks JII. Yang kedua, selisih mean antara indeks JII dan FTSE SGX Asia Shariah 100 terlihat bahwa kinerja kedua indeks hanya berbeda sebesar $-0.14 \%$ dengan indeks FTSE SGX Asia Shariah 100 memiliki kinerja lebih baik dibandingkan dengan indeks JII. Dan yang ketiga, selisih mean antara indeks JII dan indeks DJIMII terlihat bahwa kinerja kedua indeks tersebut hanya berbeda sebesar $-0.31 \%$ dengan DJIMII memiliki kinerja yang lebih tinggi dibandingkan dengan indeks JII.

Perbedaan yang tidak signifikan tersebut juga dialami oleh penelitian sebelumnya yaitu penelitian yang dilakukan oleh Al-Baity (2011) yang melihat kinerja return serta leverage serta tanggung jawab sosial (CSR) dengan menggunakan indeks saham syariah yaitu Dow Jones Islamic Market Index (DJIMII) dan FTSE Global Islamic Indices (FTSE GII). Hasil dari penelitian tersebut mengatakan bahwa tidak ada perbedaan yang signifikan return saham antara DJIMII dan FTSE GII.

\section{Kinerja Saham Syariah}

Hasil penelitian selanjutnya membandingkan kinerja saham syariah antara saham JII dengan saham FBMS Shariah yang dilihat melalui return aktual (Ri) dan abnormal return (AR) masing-masing. Hasil penelitian juga menunjukkan perbedaan yang tidak signfikan pada kinerja saham syariah. Kemudian penelitian ini mencoba menjabarkan kinerja saham syariah dengan cara memisahkan periodenya masing-masing dengan harapan penjabaran tersebut dapat memperoleh hasil yang signifikan. Ternyata meskipun periode tersebut sudah dipisahkan hasil yang diperoleh belum juga signifikan. Hasil nilai rata-rata (mean) pada return aktual (Ri) dan Abnormal Return (AR) juga menunjukkan hasil yang tidak berbeda. Nilai rata-rata (mean) dari saham JII dan saham FBMS sebesar:

Tabel 8. Selisih Nilai Rata-Rata Return Aktual Saham JII dan Saham FBMS Shariah

\begin{tabular}{lcc}
\hline \multicolumn{1}{c}{ Periode } & Selisih Mean & Keterangan \\
\hline Januari -Desember 2011 & $-0.01 \%$ & JII $<$ FBMS \\
Januari - Desember 2012 & $0.31 \%$ & JII $>$ FBMS \\
Januari -Desember 2013 & $-1.5 \%$ & JII $<$ FBMS \\
Januari 2011 - Desember 2013 & $-0.42 \%$ & JII $<$ FBMS \\
\hline
\end{tabular}

Pada tabel di atas (Tabel 8) menunjukkan selisih dari nilai rata-rata (mean) antara saham JII dan saham FBMS Shariah. Selisih mean yang pertama pada periode Januari hingga Desember 2011 diperoleh selisih mean sebesar $-0.01 \%$ dan pada periode ini kinerja saham FBMS Shariah memiliki performa yang lebih tinggi dibandingkan dengan kinerja saham JII. Pada periode selanjutnya, yaitu pada bulan Januari hingga Desember 2012 dihasilkan selisih mean sebesar $0.31 \%$ dan pada periode ini kinerja saham JII yang memiliki performa lebih 
baik dibandingkan dengan kinerja saham FBMS Shariah. Selanjutnya, pada periode Januari hingga Desember 2013 selisih mean sebesar $-0.15 \%$ dengan saham FBMS Shariah yang memiliki kinerja lebih baik dibandingkan dengan saham JII. Kemudian, hasil selisih mean mulai dari periode Januari 2011 hingga Desember 2013 menghasilkan mean sebesar $-0.42 \%$ dan saham FBMS Shariah memiliki performa lebih baik dibandingkan dengan saham JII.

Tabel 9. Selisih Nilai Rata-Rata Abnormal Return Saham JII dan Saham FBMS Shariah

\begin{tabular}{lcc}
\hline \multicolumn{1}{c}{ Periode } & Selisih Mean & Keterangan \\
\hline Januari -Desember 2011 & $-0.18 \%$ & JII $<$ FBMS \\
Januari - Desember 2012 & $0.44 \%$ & JII $>$ FBMS \\
Januari -Desember 2013 & $-0.36 \%$ & JII $<$ FBMS \\
Januari 2011 - Desember 2013 & $-0.03 \%$ & JII $<$ FBMS \\
\hline
\end{tabular}

Pada tabel 9 dapat dilihat selisih mean masing-masing dari abnormal return (AR) saham syariah antara saham JII dan saham FBMS Shariah. Hasil selisih mean yang pertama periode Januari hingga Desember 2011 dihasilkan selisih mean yaitu sebesar $-0.18 \%$ dan kinerja saham FBMS Shariah memiliki kinerja yang lebih baik dibandingkan dengan kinerja saham JII. Selanjutnya, pada periode Januari hingga Desember 2012 selisih mean yang dihasilkan sebesar $0.44 \%$ degan kinerja saham tertinggi dimiliki oleh saham JII. Pada periode berikutnya di tahun 2013 menghasilkan selisih mean sebesar $-0.36 \%$ dengan kinerja saham yang juga dipimpin oleh saham FBMS Shariah. Pada akhirnya pada periode Januari 2011 hingga Desember 2013 kinerja saham FBMS Shariah memiliki performa yang lebih tinggi dibandingkan dengan kinerja saham JII dengan selisih mean sebesar $-0.03 \%$.

Hal ini juga dialami oleh penelitian sebelumnya yang dilakukan oleh Mifrahi (2012) yang membandingkan kinerja saham syariah antara DES (Daftar Efek Syariah) Indonesia dengan DES Malaysia yang disaring (screening) dengan menggunakan syariah stock screening Malaysia yang diukur dengan pengukur M2. Hasil penelitian tersebut juga membuktikan bahwa meskipun telah memakai screening Malaysia ternyata belum juga mampu meningkatkan kinerja yang lebih baik pada DES Indonesia.

\section{Kinerja Indeks Saham Syariah dan Saham Syariah Setelah Apresiasi dan Depresiasi}

Pada akhirmya penelitian ini mencoba melihat dari apresiasi dan depresiasi kurs mata uang di negara-negara terkait. Dengan melihat apresiasi dan depresiasi antar kurs mata uang diharapkan dapat meningkatkan tingkat signifikasi pada kinerja indeks saham syariah dan kinerja saham syariah di negara-negara tersebut yang dilihat dari selisih nilai apresiasi dan depresiasi. Di bawah ini merupakan hasil perbandingan kinerja indeks saham syariah dan kinerja saham syariah setelah adanya apresiasi dan depresiasi mata uang:

Tabel 10. Hasil Perbandingan Return Aktual Indeks Saham Syariah Setelah Apresiasi.

\begin{tabular}{lccc}
\hline \multicolumn{1}{c}{ Indeks Saham Syariah } & Nilai Rata-Rata Apresiasi Per-Bulan & Selisih Mean dari JII & Selisih Total \\
\hline FBMS Shariah & $0.5 \%$ & $0.04 \%$ & $0.54 \%$ \\
FTSE SGX Asia Shariah 100 & $0.6 \%$ & $0.14 \%$ & $0.74 \%$ \\
DJIMI & $0.8 \%$ & $0.31 \%$ & $1.11 \&$ \\
\hline
\end{tabular}

Hasil pada tabel di atas (Tabel 10) hasil perbandingan return setelah mempertimbangkan apresiasi mata uang. Hasil selisih total antara JII dan FBMS Shariah sebesar 0.54\% dengan selisih sebesar 0.04\%. Kemudian perbandingan antara indeks JII dan indeks FTSE SGX Asia Shariah 100 menghasilkan selisih total sebesar $1.04 \%$ dengan selisih mean dari JII sebesar $0.14 \%$. Selanjutnya antara indeks JII dan indeks DJIMI yang menghasilkan selisih total sebesar $1.11 \%$ dengan selisih mean dari JII sebesar $0.31 \%$.

Selanjutnya, hasil perbandingan return aktual saham JII dan saham FBMS Shariah setelah apresiasi dan depresiasi mata uang. Pada Tabel 11 hasil menunjukkan bahwa pada periode Januari - Desember 2011 hasil akhir dari selisih total yang dihasilkan sebesar $-0.29 \%$ dengan selisih sebesar $0.01 \%$. Kemudian pada periode Januari - Desember 2012 hasil akhir selisih total yang dihasilkan sebesar $1.61 \%$. Pada periode Januari Desember 2013 hasil selisih total sebesar 2.8\%. Pada akhirnya selisih total dari keseluruhan periode yaitu Januari 2011 - Desember 2013 hasil akhir nilai mean yang dihasilkan sebesar 1.22\%. Kemudian hasil perbandingan 
kinerja saham JII dan saham FBMS yang dilihat dari abnormal return (AR) setelah adanya apresiasi dan depresiasi mata uang. Hasil perbandingannya dapat dilihat pada Tabel 12.

Tabel 11. Hasil Perbandingan Return Aktual Saham JII dan Saham FBMS Shariah Setelah Apresiasi dan Depresiasi

\begin{tabular}{cccc}
\hline \multicolumn{1}{c}{ Periode } & Nilai Rata-Rata Apresiasi-Depresiasi Saham & Selisih Mean & Selisih Total \\
\hline Januari - Desember 2011 & $-0.3 \%$ & $0.01 \%$ & $-0.29 \%$ \\
Januari - Desember 2012 & $1.3 \%$ & $0.31 \%$ & $1.61 \%$ \\
Januari - Desember 2013 & $1.3 \%$ & $1.5 \%$ & $2.8 \%$ \\
Januar 2011 - Desember 2013 & $0.8 \%$ & $0.42 \%$ & $1.22 \%$ \\
\hline
\end{tabular}

Tabel 12. Hasil Perbandingan Abnormal Return Saham JII dan

Saham FBMS Shariah Setelah Apresiasi dan Depresiasi

\begin{tabular}{lccc}
\hline \multicolumn{1}{c}{ Periode } & $\begin{array}{c}\text { Nilai Rata-Rata Apresiasi-Depresiasi } \\
\text { Saham }\end{array}$ & $\begin{array}{c}\text { Selisih } \\
\text { Mean }\end{array}$ & $\begin{array}{c}\text { Selisih } \\
\text { Total }\end{array}$ \\
\hline Januari - Desember 2011 & $-0.3 \%$ & $0.18 \%$ & $-0.12 \%$ \\
Januari - Desember 2012 & $1.3 \%$ & $0.44 \%$ & $1.74 \%$ \\
Januari - Desember 2013 & $1.3 \%$ & $0.36 \%$ & $1.66 \%$ \\
Januar 2011 - Desember & $0.8 \%$ & $0.03 \%$ & $0.83 \%$ \\
2013 & & & \\
\hline
\end{tabular}

Pada tabel selanjutnya (Tabel 12) penjabaran dari masing-masing periode setelah mempertimbangkan apresiasi dan depresiasi mata uang Rupiah terhadap Ringgit. Pertama, pada periode Januari - Desember 2011 selisih total yang dihasilkan sebesar $-0.12 \%$. Periode Januari - Desember 2012 perbandingan kinerja kedua saham menghasilkan selisih total sebesar sebesar 1.74\%. Pada periode Januari - Desember 2013, selisih total yang dihasilkan sebesar $1.66 \%$. Kemudian yang terakhir hasil perbandingan dari keseluruhan periode (Januari 2011 - Desember 2013) selisih total yang dihasilkan sebesar $0.83 \%$.

\section{Kesimpulan}

Kinerja indeks saham syariah ternyata tidak dipengaruhi oleh seberapa ketat proses screening dari indeks tersebut. Meskipun secara statistik indeks saham syariah yang mempunyai kebijakan screening saham paling ketat adalah indeks KLSESI yang ternyata tidak berbeda dengan indeks saham syariah yang mempunyai kebijakan screening saham paling longgar yaitu pada indeks DJIMI. Sementara jika dilihat dari return masingmasing indeks, hasil analisis perbandingan kinerja keempat indeks tersebut menujukkan hasil yang tidak signifikan. Kinerja saham JII yang memiliki kebijakan screening saham lebih longgar juga tidak berbeda dengan kinerja saham KLSESI yang memiliki kebijakan screening saham yang lebih ketat. Meskipun dalam melakukan kebijakan screening saham pada saham JII membutuhkan waktu 6 bulan sekali untuk melakukan pengkajian ulang (penyaringan) untuk menentukan perusahaan-perusahaan yang akan masuk ataupun keluar dari indeks JII. Sedangkan untuk saham-saham KLSESI yang juga dilihat berdasarkan tingkat likuiditas dan nilai kapitalisasi pasar yang tinggi menunjukkan pergerakan yang selalu berubah-ubah setiap harinya. Hasil perbandingan return aktual dan abnormal return antara kedua saham menunjukkan perbedaan yang tidak signifikan meskipun sudah mengelompokkan berdasarkan periode masing-masing. Hal ini juga dikarenakan return aktual dan abnormal return yang dimiliki oleh saham KLSESI sebagian besar memiliki nilai yang tinggi di setiap periodenya.

Bagi investor Indonesia jika ingin melakukan investasi pada saham-saham asing perlu mempertimbangkan adanya apresiasi dan depresiasi mata uang Rupiah terhadap mata uang Negara lain. Karena salah satu pertimbangan yang harus diperhatikan dalam pengambilan keputusan investasi pada saham asing selain melihat dari return yang dihasilkan investor juga harus melihat apresiasi dan depresiasi mata uang. Hal ini juga menjadi semacam ijtihad (upaya) bagi para regulator untuk mendorong perkembangan pasar saham syariah yang melihat perbedaan screening saham di berbagai negara dan bagaimana upaya para regulator mengharmonisasikan adanya perbedaan tersebut. Kemudian secara bersama-sama mewujudkan apa yang menjadi tujuan dan pencapaian dari ekonomi islam yaitu maslahah. 


\section{Daftar Pustaka}

Achsien, I. H. (2000). Investasi Syariah di Pasar Modal: Menggagas Konsep dan Praktek Manajemen Portofolio Syariah. Jakarta: Gramedia

Albaity, A. (2011). Return Performance and Leverage Effect in Islamic and Socially Responsible Stock Indices Evidence from Dow Jones (DJ) and Financial Times Stock Exchange (FTSE), African Journal of Business Management, 5 (16), 6927-6939

Basri, (2014), Perbandingan Kinerja Saham Syariah dan Saham Konvensional di Bursa Efek Indonesia, Efektif, Jurnal Bisnis dan Ekonomi, 5(2), 127-147

Hadita, J \& Taufikurohman, M.R, (2011) Analisis Perbandingan Kinerja Portfolio Saham-Saham Jakarta islamic Index pada Pasar Bullish dan Bearish, Tazkia Islamic Business and Finance Review, 6(1), 50-64

Hanafi, M. (2012). Perbandingan Kinerja Investasi Syariah dan Konvensional: Studi pada Jakarta Islamic Index (JII) dan Indeks LQ45, EKBISI, 7 (1), 16-27

Hartono. 2013, Teori Portofolio dan Analisis Investasi, Ed. 7. Yogyakarta: BPFE

Hussein, K. (2004), Ethical Investment : Empirical Evidence From FTSE Islamic Index, Islamic Economics Studies, 12 (1), 21-40

Mifrahi, M. N. (2012). Perbandingan Kinerja Syariah Berbasis Syariah Stock Screening yang Berlaku di Indonesia, Malaysia, dan Gabungan Keduanya, EKBISI, 7 (2), 214-232

Nurlatifah, (2011), Analisis Perbandingan Antara Kinerja Saham Jakarta Islamic Index (JII) dan Non-JII di Bursa Efek Indonesia Selama Periode 2007-2009, Jurnal Akuntansi dan Bisnis, 2(3), 1-20

Obaidullah, (2008). Ethics and Efficiency in Islamic Stock Market, International Journal of Islamic Financial Services, 3(2), 15-23

Trevor, L.N. (2006). Islamic Investment Funds, London: Euro Money Books 